\title{
Pengelolaan Persandian Dalam Menjaga Informasi Rahasia Negara Pada Pemerintah Kabupaten Bungo
}

\author{
Ridwan \\ Progaram Studi Ilmu Pemerintahan \\ Fakultas Ilmu Sosial dan Politik, Universitas Muara Bungo \\ Jl.Diponegoro No.27 Muara Bungo, Jambi \\ email: iwan09ukm@gmail.com \\ Mulia Jaya \\ Progaram Studi Ilmu Pemerintahan \\ Fakultas Ilmu Sosial dan Politik, Universitas Muara Bungo \\ Jl.Diponegoro No.27 Muara Bungo, Jambi \\ email: lakers_krc@gmail.com

\section{Rusdi} \\ Sub Bagian Persandian Kabupaten Bungo \\ Jl. RM. Thaher No. 503, Pasar Muara Bungo, Bungo, Kota Jambi, 37214 \\ email: rusdi_bgo@gmail.co.id
}

\begin{abstract}
Encoding is one of the mandatory matters that is not related to basic services. To elaborate regional authority related to coding matters, mapping of coding affairs is carried out in the context of structuring the Provincial / Regency / City Regional Institutional Apparatus in the Field of Encoding according to the direction of Law No. 23 of 2014 concerning Regional Government. With the enactment of Law Number 23 Year 2014 in the Jambi Provincial Government, especially in the Bungo District, realizing harmonization of policies between the center and the regions that synergize with each other and will achieve the goals of Regional Autonomy in the welfare of people's lives. In the Bungo Regency in the coding activity supported by 17 sub-districts within the Regency area, the implementation was not yet optimal. This research uses qualitative research methods, qualitative research has a flexible nature. This research found that the implementation of the duties and functions of the Bungo Regency coding team in maintaining confidential government information in the context of efforts to realize the integrity of the Unitary State of the Republic of Indonesia (NKRI) had not gone well. This is evidenced by the lack of awareness and responsibility of the coding team on the duties and functions of the coding field. Obstacles or obstacles faced
\end{abstract}


178 | Ridwan,Mulia,Rusdi. Pengelolaan Persandian...

by the coding team in carrying out their functions in safeguarding confidential government information in an effort to realize the integrity of the Unitary State of the Republic of Indonesia, including lack of awareness and full support from superiors or officials authorized to carry out coding functions and functions, there is no means from the government in the implementation of duties and functions in the coding field.

Keywords: Management, encryption, information, confidential, State

\begin{abstract}
Abstrak
Persandian merupakan salah satu urusan wajib yang tidak berkaitan dengan pelayanan dasar. Untuk menjabarkan kewenangan daerah terkait urusan persandian maka dilakukan Pemetaan Urusan Persandian dalam rangka penataan Kelembagaan Perangkat Daerah Provinsi/Kabupaten/Kota Bidang Persandian sesuai arah Undang - undang (UU) Nomor 23 Tahun 2014 tentang Pemerintah Daerah. Dengan berlakunya UU Nomor 23 Tahun 2014 di Pemerintah Provinsi Jambi khususnya di Kabupaten Bungo akan mewujudkan harmonisasi kebijakan antara pusat dan daerah yang saling bersinergi dan akan tercapai cita - cita Otonomi Daerah dalam mensejahterakan kehidupan masyarakat. Dikabupaten Bungo dalam kegiatan persandian yang didukung oleh 17 kecamatan dalam wilayah Kabupaten namun pelaksanaannya belum maksimal. Penelitian ini menggunakan metode penelitian kualitatif yaitu penelitian kualitatif memiliki sifat fleksibel. Penelitian ini menemukan bahwa pelaksanaan Tugas dan Fungsi Tim Persandian kabupaten Bungo dalam menjaga informasi rahasia pemerintah dalam rangka upaya untuk mewujudkan keutuhan Negara Kesatuan Republik Indonesia (NKRI) belum berjalan dengan baik. Hal tersebut dibuktikan dengan adanya kesadaran dan tanggung jawab Tim Persandian yang kurang terhadap Tugas dan Fungsi Bidang Persandian. Hambatan atau kendala yang dihadapi Tim Persandian dalam melaksanakan fungsinya dalam menjaga informasi rahasia pemerintah dalam rangka upaya untuk mewujudkan keutuhan Negara Kesatuan Republik Indonesia diantaranya kurangnya kesadaran dan dukungan penuh dari atasan atau pejabat yang berwenang terhadap pelaksanaan tugas dan fungsi persandian, tidak adanya sarana dari pemerintah dalam pelaksanaan tugas dan fungsi di bidang persandian.
\end{abstract}

Kata kunci: Pengelolaan, persandian, informasi, rahasia, negara

\title{
I. Pendahuluan
}

Di Era Globalisasi saat ini, sering pula disebut Abad Informasi, Teknologi Informasi dan Komunikasi (INFOKOM) sudah menjadi sebuah trend yang mempengaruhi seluruh aspek kehidupan manusia termasuk bidang pertahanan dan keamanan atau militer, melalui 
revolusi IPTEK Informasi dan Komunikasi (IPTEK INFOKOM) yang merupakan konvergensi antara jaringan perangkat komputer dan telekomunikasi dalam wujud jaringan koneksi global (Internet).

Perkembangan teknologi informasi yang pesat memberikan pengaruh cukup besar terhadap peradapan manusia. Secara langsung perkembangan tersebut mempengaruhi kebutuhan pokok manusia dalam memperoleh informasi secara cepat, tepat dan akurat serta memainkan peran penting dalam berbagai aspek kehidupan manusia, seperti alat bantu dalam proses pengambilan keputusan penentuan sebuah kebijakan atau bahkan tren atau gaya hidup medern.

Informasi adalah aset sekaligus ancaman. Informasi menjadi aset bila bermanfaat dan tersampaikan secara aman dan utuh, baik dalam bentuk maupun dalm makna. Informasi menjadi ancaman jika jatuh kepihak yang tidak berwenang, yang menjadikannya senjata untuk menjatuhkan ${ }^{1}$.

Melalui perangkat teknologi informasi seperti radio, televisi, komputer, jaringan internet dan telepon seluler, arus informasi berkembang dengan pesatnya. Saat ini tidaklah membutuhkan waktu yang lama untuk mendapatkan informasi dari belahan bumi lainnya pada hari yang sama. Kemajuan teknologi informasi dan komunikasi benar - benar telah diakui dan dirasakan manfaatnya oleh manusia dengan adanya berbagai kemudahan dan kenyamanan bagi kehidupan umat manusia.

Pengamanan informasi, baik informasi pemerintah di tingkat lokal maupun menyangkut rahasia negara, menjadi sangat penting dalam melindungi keutuhan Negara Kesatuan Republik Indonesia (NKRI). Penyelenggaraan negara yang mengeluarkan sembarangan informasi bisa membahayakan keutuhan NKRI.

Implementasi teknologi informasi pada dunia maya melalui akses internet, baik yang berbayar ataupun fasilitas layanan wi-fi gratis yang tersedia di bandara, stasiun kereta api serta tempat - tempat umum pelanyanan publik saat ini meningkat pesat, sehingga memungkinkan terjadinya kebocoran informasi pribadi atau rahasia perusahaan maupun pemerintah yang bisa digunakan untuk tidakan kriminal. Kasus penipuan juga marak terjadi tindakan kejahatan atau kriminalitas di dunia maya biasa kita kenal dengan dunia siber (cyber crimes) kebocoran informasi merupakan peluang bagi pelaku kejahatan dalam mengambil keuntungan pada aktivitas transaksi yang dilakukan di dunia maya tersebut. Sebagai contoh serangan - serangan dan pencurian data terhadap berbagai situs baik milik

\footnotetext{
${ }^{1}$ Lemsaneg RI, Jelajah Kriptologi, 2007, halaman:17.
} 
pemerintah maupun situs - situs komersial dan perbankan tidak terkecuali kemungkinan serangan terhadap situs - situs milik institusi strategis di Indonesia².

Keutuhan NKRI perlu didukung oleh sistem pengamanan informasi negara yang aman dan handal. untuk itu sistem pengamanan dimaksud perlu ditunjang dengan sistem persandian yang memadai. istilah"sandi"telah mulai dipakai sejak masa kerajaan-kerajaan di tanah air dulu, seperti kerajaan Majapahit, saat itu telah muncul istilah " Telik Sandi", " Candra Sengkala " dan lainnya yang sedikit banyak mempunyai hubungan dengan persandian. Dalam perkembangannya persandian di mulai dari upaya pihak lawan untuk memperolah informasi yang dapat dijadikan senjata. Mulai dari teknik konvensional hingga implementasi teknologi canggih, yang digunakan untuk memperoleh informasi. Gerakan ini sudah dimulai sejak perang dimasa Romawi kuno, atau mungkin dimasa-masa sebelumnya yang bertumpu pada perang fisik, hingga ketika ancaman tidak lagi terbatas pada serangan fisik, tetapi telah berkembang kearah perang digital.

Pada masa era digital saat ini, dalam memperoleh informasi bisa dilakukan dengan cara penyadapan informasi seperti pada peristiwa perang Teluk (1990-1991), pada kurun waktu antara April 1990 hingga Mei 1991, lima orang penyadap elektronik ( hackers ) berbangsa Belanda berhasil menembus sistem komunikasi Amerika di 34 situs militer dalam internet. Mereka menelusuri seluruh ruang gerak komputer ( cyberspace) untuk memperoleh informasi pada waktu pengirimannya ( in transit ), dalam proses en/dekripsi ( in Processing ) ataupun sudah tersimpan ( in storage, filed ). Untuk mencari seluruh teks teks yang mengandung kata - kata kunci seperti Nuclear, missiles dan weapons, bahkan, mereka berhasil memperoleh informasi mengenai lokasi pasukan Amerika, persenjataannya, kemampuan missele- nya. dan gerakan - gerakan kapal perangnya di Teluk Arab( The Gulf War $)^{3}$.

Tujuan kegiatan persandian adalah pengamanan informasi yang diarahkan untuk menjaga kerahasiaan(confidentiality), keutuhan(integrity), keaslian (authentication), dan tidak ada penyangkal (non repudiation). Informasi yang disandikan. Beriringan dengan itu berbagai upaya mengamankan informasi juga dilakukan, mulai dari penyembunyian tulisan rahasia dalam selembar sutra yang disembunyikan dalam parut atau rectum seorang kurir, tulisan yang diacak dan disisipkan dalam surat cinta, tulisan yang huruf- hurufnya diganti dengan huruf lain dengan pola tertentu, hingga mekanisasi sampai digitalisasi penulisan rahasia melalui sistem, kesemuanya itu bermuara pada suatu kebutuhan, mengamankan

\footnotetext{
${ }^{2}$ Materi diklat sandi

${ }^{3}$ Lemsaneg RI, JELAJAH KRIPTOLOGI, 2007, halaman:19.
} 
informasi dan menjamin informasi sampai pada tujuan yang tepat secara utuh, aman dan benar.

Persandian merupakan salah satu urusan wajib yang tidak berkaitan dengan pelayanan dasar. Untuk menjabarkan kewenangan daerah terkait urusan persandian maka dilakukan Pemetaan Urusan Persandian dalam rangka penataan Kelembagaan Perangkat Daerah Provinsi/Kabupaten/Kota Bidang Persandian sesuai arah Undang - undang (UU) Nomor 23 Tahun 2014 tentang Pemerintah Daerah. Pada UU tersebut, telah ditetapkan bahwa urusan persandian adalah urusan pemerintah konkuren yang bersifat wajib bagi seluruh pemerintah daerah di tingkat provinsi, kabupaten, dan kota. Dalam pengaturannya secara jelas diamanatkan bahwa intansi pusat wajib melakukan pembinaan dan pengawasan teknis kepada pemerintah provinsi, selanjutnya pemerintah provinsi melakukan pembinaan dan pengawasan kepada pemerintah kabupaten/kota dibawahnya.

Penerapan Undang - undang Nomor 23 Tahun 2014 tersebut, khususnya pada bidang persandian menegaskan bahwa fungsi persandian bukan hanya sebatas kirim terima surat/berita sandi, akan tetapi diperluas sebagai suatu bentuk pengamanan informasi yang diharapkan akan mewujudkan keutuhan Negara Kesatuan Republik Indonesia (NKRI). Selain hal tersebut, diharapkan dengan berlakunya UU Nomor 23 Tahun 2014 diPemerintah Provinsi Jambi akan mewujudkan harmonisasi kebijakan antara pusat dan daerah yang saling bersinergi dan akan tercapai cita - cita Otonomi Daerah dalam mensejahterakan kehidupan masyarakat.

Adapun pelaksanaan urusan Persandian di Kabupaten Bungo sesuai dengan Peraturan Bupati Bungo Nomor 55 Tahun 2016 dilaksanakan oleh Sub Bagian Persandian, adapun Staf Persandian pada Sub Bagian Persandian Kabupaten Bungo yaitu :

Tabel I. Staf Sub Bag. Persandian Kab.Bungo

\begin{tabular}{|l|l|l|c|}
\hline No & \multicolumn{1}{|c|}{ Nama } & Pangkat / Golongan & Jabatan \\
\hline 1 & Hasan Bahari & Penata,Tk.I III/d & Ka. Sub Bag. Persandian \\
\hline 2 & Darmadi & Penata Muda TK.I III/b & Staf \\
\hline 3 & Sunadi, S.Sos. & Penata TK.I III/a & Staf \\
\hline 4 & Rusdi & Pengatur Muda, II/b & Staf \\
\hline 5 & Rica Andriana & Honor Kontrak & Staf \\
\hline
\end{tabular}

(Sumber; Sub Bag.Persandian Kab.Bungo). 
Tabel II. Pendukung Urusan Persandian di Kecamatan

\begin{tabular}{|c|c|c|}
\hline No & Nama & Kecamatan \\
\hline 1 & Hera & Tanah Tumbuh \\
\hline 2 & Syamsir & Limbur LM. \\
\hline 3 & Heni & Bahtin II Babeko \\
\hline 4 & Mardianis, Amd & Muko-Muko Bathin VII \\
\hline 5 & Yanos & Rantau Pandan \\
\hline 6 & Dian Novi & Tanah Sepenggal \\
\hline 7 & Tika & Jujuhan \\
\hline 8 & Imas & Pelepat \\
\hline 9 & Mardiyana & Pelepat Ilir \\
\hline 10 & Leha & Bathin III Ulu \\
\hline 11 & Endang,S. & Jujuhan Ilir \\
\hline 12 & Yeni & Bathin II Pelayang \\
\hline 13 & Efriyanto & Tanah Sepenggal Lintas \\
\hline 14 & - & Bathin III \\
\hline 15 & - & Pasar Muara Bungo \\
\hline 16 & - & Bungo Dani \\
\hline 17 & - & Rimbo Tengah \\
\hline
\end{tabular}

(Sumber : Sub Bag. Persandian Kab.Bungo).

Ada beberapa hal yang dapat mendukung terlaksananya pelaksanaan urusan persandian di Kabupaten Bungo diantaranya yaitu :

1. Sumberdaya Manusia

Sumberdaya manusia adalah merupakan faktor utama dalam pelaksananan kegiatan Persandian dalam Kabupaten Bungo.

2. Paralatan dan Infrastruktur.

Peralatan dan infrastruktur adalah merupakan faktor pendukung utama dalam pelaksanaan kegiatan persandian di Kabupaten Bungo.

3. Budgetting (Keuangan/Anggaran)

Keuangan/anggaran adalah sangat diperlukan dalam mendukung pembiayaan kegiatan Persandian. 
Dikabupaten Bungo dalam kegiatan persandian yang didukung oleh 17 kecamatan dalam wilayah Kabupaten. Sedangkan permasalahan yang ada diantaranya :

1. Peralatan Radio Telekomunikasi sebagai pendukung kegiatan Persandian di Kecamatan banyak mengalami kerusakan, dari 17 kecamatan hanya 2 kecamatan yang memiliki Radio Telekomunikasi yang masih Bagus (Kec. Bathin II Babeko dan Kec.Muko - Muko Bathin VII).

2. Pemerintah Kabupaten Bungo belum memiliki teknisi dibidang Telekomunikasi hal ini mengakibatkan Radio Telekomunikasi yang rusak tidak dapat di perbaiki.

3. Kesadaran dan partisipasi serta tanggung jawab pegawai untuk menjaga dan merawat peralatan Radio Telekomunikasi masih kurang, terutama di kecamatan.

Mengingat vitalnya peran persandian dalam pengamanan rahasia Negara terutama di Kabupaten Bungo maka pengelolaan persandian yang baik dan profesional sangat dibutuhkan. Sebagaimana ungkapan Sekretaris Dinas Kominfo dan Persandian Kabupaten Bungo maka di dinas ini terdapat seksi pengamanan dan pengembangan infrastruiktur dasar pusat data ${ }^{4}$.

\section{Tinjauan Pustaka}

\section{a. Sandi}

Kata "sandi" berasal dari bahasa Sansekerta yaitu 'Sandhi".yang bearti rahasia, sedangkan arti kata sandi dalam bahasa Indonesia adalah; rahasia, kode ${ }^{5}$. Dimana didalamnya memiliki pengertian yang berkaitan dengan maksud - maksud tertentu(Pesan atau berita), berhubungan (komunikasi), perlindungan dan kerahasiaan. Proses komunikasi yang terdiri atas proses rohaniah komunikator dan proses rohaniah komunikan adalah proses membuat sebuah pesan setala (tuned) bagi komunikator dan komunikan. Pertama tama komunikator menyandi (encode) pesan yang akan disampaikan kepada komunikan. Ini bearti ia memformulasikan pikiran dan / atau perasaannya kedalam lambang (bahasa) yang diperkirakan akan dimengerti oleh komunikan, kemudian menjadi giliran komunikan untuk mengawa- sandi (decode)pesan dari komunikator itu. Ini bearti ia menafsirkan lambang yang mengandung pikiran dan atau perasaan komunikator tadi dalam konteks

\footnotetext{
${ }^{4}$ https://bungoindependent.id/read/2020/01/24/10993/dis-kominfo-jadi-pusat-informasi-dan-data, diakses tanggal 20 Februari 2020 pukul 06.53 Wib

${ }^{5}$ Brian Prabaswara, Kamus Praktis Bahasa Indonesia,Lingkar Media,halaman ; 327
} 
pengertiannya. Dalam proses itu komunikator berfungsi sebagai penyandi (encoder) dan komunikan berfungsi sebagai pengawa- sandi (decoder) ${ }^{6}$.

Yang paling penting dalam proses penyandian (coding) itu ialah bahwa komunikator dapat menyandi dan komunikan dapat mengewa-sandi hanya kedalam kata bermakna yang pernah diketahui dalam pengalamannya masing - masing. Wilbur Schramm, seorang ahli komunikasi kenamaan, dalam karyanya, "Communication Research in the United State", menyatakan bahwa komunikasi akan berhasil apabila pesan yang disampaikan oleh komunikator cocok dengan kerangka acuan (Frame of reference), yakni paduan pengalaman dan pengertian (collection of experiences and meanings) yang pernah diperoleh komunikan.

Menurut Schramm, bidang pengalaman (field of experience) merupakan faktor yang penting dalam komunikasi. Jika bidang pengalaman komunikator sama dengan bidang pengalaman komunikan, komunikasi akan berlangsung lancar. Sebaliknya, bila pengalaman komunikasi tidak sama dengan pengalaman komunikator, akan timbul kesukaran untuk mengerti satu sama lain.

Dalam proses komunikasi antar persona (interpersonal communication) yang melibatkan dua orang dalam situasi interaksi, komunikator menyandi suatu pesan, lalu menyampaikan kepada komunikan, dan komunikan mengawasandi pesan tersebut. Sampai disitu komunikator menjadi encoder dan komunikan menjadi decoder. Akan tetapi, karena komunikasi antar personal itu bersifat dialogis, maka ketika komunikan memberikan jawaban, ia kini menjadi encoder dan komunikator menjadi decoder. Untuk jelasnya, jika komunikator itu bernama A dan komunikan bernama B, maka selama komunikasi berlangsung antara $A$ dan $B$ itu, akan terjadi penggantian fungsi secara bergiliran sebagai encoder dan decoder. Jika A sedang berbicara, ia menjadi encoder; dan $B$ yang sedang mendengarkan menjadi decoder. Ketika B memberikan tanggapan dan berbicara kepada $A$, maka B kini menjadi encoder dan A menjadi decoder.Tanggapan B yang disampaikan kepada A itu dinamakan umpan balik atau arus balik (feedback) ${ }^{7}$.

Lahirnya persandian di Indonesia sungguh merupakan fenomena yang layak dicatat (remarkable). Pengetahuan dan kegiatan persandian pada era penjajahan Belanda sampai Maret 1942, tidak penah dipercayakan kepada pribumi Indonesia. Profesi sandi hanya untuk bangsa Belanda"totok", Belanda Asli.

\footnotetext{
${ }^{6}$ Onong Uchjana Effendi,Ilmu Komunikasi Teori dan Praktek,PT Remaja Rosdakarya,2002,hlm:13

${ }^{7}$ Onong Uchjana Effendy,Ilmu Komunikasi Teori dan Praktek, PT Remaja Rosakarya,Bandung,2002,halaman : 13 14.
} 
Roebiono Kertopati (RK) dipercaya oleh pemerintah Republik Indonesia untuk mendirikan Dinas Code pada April 1946, RK menghadapi tugas berat; karena sistem sandi dengan segala atribut - atribut yang melekat padanya (pengamanan personil dan fisik) sama sekali tidak dikenal. Namun RK tidak mulai dengan awal, khususnya sistem sandi yang diajarkan sekaligus dipakai dalam praktek, adalah sistem yang benar - benar 'unbreakable", seperti Code dan Rangkaian kunci, yang dinyatakan oleh para pakar berbagai Negara maju."Learning by doing" memang benar - benar sangat efisien pada masa $i^{8}{ }^{8}$. Adapun penjelasan keputusan Menteri dalam Negeri tentang Penyelenggaraan Sandi dan Telekomunikasi di Jajaran Departemen Dalam Negeri adalah sebagai berikut :

1) Sandi adalah susunan huruf, tulisan(kata,tanda dan lain sebagainya) yang diproses secara Kriptografis dan menghasilkan suatu bentuk Kriptogram ;

2) Sandiman adalah Pegawai Negeri Sipil dan Prajurit TNI yang memiliki keahlian sandi dan diberi tugas, tanggung jawab, wewenang dan hak oleh pejabat yang berwenang untuk melaksanakan tugas/ kegiatan persandian pada intansi pemerintah dan badan - badan lain;

3) Persandian adalah suatu usaha /tindakan /kegiatan yang dilakukan untuk mengamankan setiap berita rahasia dan rahasia negara melalui proses sandi -menyandi(kriptografis) ;

4) Telekomunikasi adalah setiap pemancaran, pengiriman atau penerimaan setiap jenis tanda, gambar, suara dan informasi dalam bentuk apapun melalui sistem kawat, optik, radio atau sistem elektromagnetik lainnya ;

5) Alat Telekomunikasi adalah setiap alat perlengkapan yang digunakan dalam bertelekomunikasi;

6) Perangkat Telekomunikasi adalah sekelompok alat telekomunikasi yang memungkinkan bertelekomunikasi ;

7) Jaringan Telekomunikasi adalah rangkaian perangkat telekomunikasi dan kelengkapannya yang digunakan dalam rangka bertelekomunikasi ;

Adapun mengenai urusan persandian Sub Bagian Persandian memiliki akses ke Lembaga Sandi Negara hal ini karena Sub Bagian Persandian Kabupaten Bungo memiliki tenaga ahli sandi.

\section{b. Pengamanan Informasi}

Informasi adalah aset sekaligus ancaman. Ia menjadi aset bila bermanfaat dan tersampaikan secara aman dan utuh, baik dalam bentuk maupun dalam makna. Ia menjadi

\footnotetext{
${ }^{8}$ Copyright Lemsaneg RI, Jelajah Kriptologi, 2007, halaman : 25.
} 
ancaman jika jatuh kepihak yang tidak berwenang yang menjadikannya senjata untuk menjatuhkan. Upaya mengamankan informasi dilakukan, mulai menyembunyikan tulisan rahasia hingga mekanisasi sampai pada digitalisasi penulisan rahasia melalui sistem kesemuanya itu bermuara pada suatu kebutuhan, mengamankan informasi dan menjamin informasi sampai tujuan yang tepat secara utuh, aman dan benar ${ }^{9}$.

Pengamanan informasi adalah melindungi informasi dari segala kemungkinan ancaman terhadap informasi yang akan berpengaruh terhadap kinerja dan prestasi organisasi dengan cara meminimalisir kerugian yang dapat ditimbulkan serta memaksimalkan keuntungan dari investasi dan peluang organisasi tersebut.

Pengamanan informasi perlu dilakukan di setiap sistem informasi, tempat informasi tersebut berada, sesuai dengan hakekat dan bentuk ancaman atau gangguan yang mungkin terjadi. Menurut W.Stalling ada beberapa kemungkinan jenis serangan (attack) :

\section{Interruption}

Perangkat sistem menjadi rusak atau tidak tersedia. Serangan ditujukan kepada ketersediaan (availability) dari sistem.

\section{Interception}

Pihak yang tidak berwenang berhasil mengakses aset atau informasi. Contoh dari serangan ini adalah penyadapan kabel (wiretapping).

\section{Modification}

Pihak yang tidak berwenang tidak saja berhasil mengakses, akan tetapi dapat juga mengubah (tamper) aset. Contoh dari serangan ini adalah mengubah isi web site dengan pesan - pesan yang merugikan pemiliknya.

\section{4. fabrication}

pihak yang tidak berwenang menyisipkan objek palsu kedalam sistem. Contoh dari serangan jenis ini adalah memasukkan pesan - pesan palsu seperti e-mail palsu kedalam sebuah jaringan komputer.

Security attack, atau serangan terhadap keamanan informasi diantaranya;

\section{1) Kesalahan persepsi}

\footnotetext{
${ }^{9}$ Copyright Lemsaneg RI, Jelajah Kriptologi, 2007, halaman : 17dan 18.
} 
Penerima tidak dapat menterjemahkan data yang diterima menjadi informasi yang sesungguhnya, dapat disebabkan karena pengetahuan yang belum sesuai atau situasi lain yang tidak mendukung termaknainya data. Hal ini dapat terjadi yang melakukannya lalai atau adanya situasi tertentuyang menyebabkan proses untuk mendapatkan persepsi yang utuh tidak / sulit dilakukan .

2) Penyadapan

Yaitu proses penyadapan dapat dimungkinkan misalnya dengan menyimpan mikrofon dan pemancar mini yang tersembunyi atau menyadap jalur kabel papan ketik untuk mendapatkan pulsa dari alat tersebut.

3) Interupsi

Interupsi dapat terjadi misal dengan adanya gelombang elektromagnetik yang mengganggu atau terputusnya sumber tenaga.

4) Pemalsuan dapat terjadi jika alat masukan telah mengalami modifikasi, sehingga hasil dari alat tersebut tidak seperti yang diharapkan.

5) Penyadapan pada alat penerima

Penyadapan pada alat penerima misal adanya perangkat keras lain yang memancar ulangkan informasi yang diterima atau terjadi kebocoran sinyal pada alat penerima.

6) Penyadapan dan interupsi

Penyadapan pada media penyimpanan dapat dilakukan dengan duplikasi atau penyalinan data.

7) Rekontruksi

Pada media penyimpana magnetis, data yang telah dihapus secara logis, masih dapat direkontruksi lagi, bahkan yang terhapus fisik pun masih dapat direkontruksi kembali.

8) Pengamatan/ pengintaian

Pengintaian dari pelaksanaan maksud informasi dengan alat tertentu atau suatu metode intelijen, dikenal pula istilah social engineering dalam sistem komputer.

Tujuan pengamana informasi secara umum adalah menjamin ketersediaan (availability), keutuhan(integrity), kerahasiaan (confidentiality), dan ketepatan tujuan sistem informasi. Tujuan tersebut jika dijelaskan secara rinci adalah ;

1. Privasi/kerahasiaan(privacy/confidentiality), yaitu menjaga kerahasian informasi dari semua pihak, kecuali yang memiliki kewenangan;

2. Integritas (integrity), menyakinkan bahwa data tidak mengalami perubahan oleh yang tidak berhak atau oleh suatu hal lain yang tidak diketahui (misalnya buruknya transmisi data) ; 
3. Otentikasi / identifikasi ( authentication / identification ), pengecekan terhadap identitas suatu entitas, bisa berupa orang, kartu kredit atau mesin;

4. Tanda tangan ( signature), mengesahkan suatu informasi menjadi satu kesatuan dibawah suatu otoritas;

5. Otorisasi ( authorization), pemberian Hak / kewenangan kepada entitas lain di dalam sistem ;

6. Validasi ( validation ), pengecekan keabsahan suatu otoritasi ;

7. Kontrol akses ( access control), pembatasan akses terhadap entitas di dalam sistem;

8. Sertifikasi ( certification), pengesahan / pemberian kuasa suatu informasi kepada entitas yang terpercaya ;

9. Pencatatan waktu ( timestamping), mencatat waktu pembuatan atau keberadaan suatu informasi di dalam sistem ;

10. Persaksian ( witnessing), memverifikasi pembuatan dan keberadaan suatu informasi di dalam sistem bukan oleh pembuatnya

11. Tanda terima ( receipt), pemberitahuan bahwa informasi telah diterima ;

12. Konfirmasi ( confirmation ), pemberitahuan bahwa suatu layanan informasi telah tersedia;

13. Kepemilikan ( ownership), menyediakan suatu entitas dengan sah untuk menggunakan atau mengirimkan kepada pihak lain ;

14. Anonimitas ( anonimity), menyamarkan identitas dari entitas terkait dalam suatu proses transaksi ;

15. Nirpenyangkalan ( non - repudiation ), mencegah penyangkalan dari suatu entitas atas kesepakatan atau perbuatan yang sudah di buat;

16. Penarikan ( revocation ), penarikan kembali suatu sertifikat atau otoritas. ${ }^{10}$

\section{Metode Penelitian}

Untuk memudahkan proses pengumpulan bahan dan data - data penelitian penelitian ini maka penelitian ini berlokasi di Kabupaten Bungo. Hal ini dikarenakan :

1. Peralatan Radio Telekomunikasi sebagai sarana pendukung kelancaran kegiatan Persandian di kecamatan banyak mengalami kerusakan.dari 17 kecamatan hanya 2 kecamatan yang memiliki Radio Telekomunikasi yang masih bagus.( Kec. Bathin II Babeko dan Kec. Muko - Muko Bathin VII ).

\footnotetext{
${ }^{10}$ Copyright Lemsaneg RI, Jelajah Kriptologi, 2007, halaman :323-328.
} 
2. Pemerintah Kabupaten Bungo belum memiliki teknisi dibidang Telekomunikasi.

3. Kesadaran dan partisipasi serta tanggung jawab pegawai untuk menjaga dan merawat peralatan Radio Telekomunikasi masih kurang, terutama di kecamatan.

Penelitian ini menggunakan metode penelitian kualitatif yaitu penelitian kualitatif memiliki sifat fleksibel. Fleksibel disini diartikan sebagai peneliti bisa saja memulai pengumpulan data dilapangan terlebih dahulu, baru setelah itu peneliti menyusun laporannya. Setelah menganalisis data yang sudah didapatnya dilapangan, peneliti bisa memutuskan untuk kembali lagi kelapangan untuk mengumpulkan data. Kondisi ini yang sering disebut dengan "logic in practis". Jika dalam penelitian kuantitatif instrument penelitian yang digunakan umumnya dalam bentuk kuesioner, didalam kualitatif peneliti adalah instrumen penelitian. Dengan demikian kualitas data yang akan dihasilkan benar benar berada ditangan peneliti. Demikian pula halnya jika didalam penelitian kuantitatif peneliti bisa minta bantuan orang lain untuk mengumpulkan data dilapangan, maka dalam penelitian kualitatif sebaiknya peneliti sendirilah yang harus turun kelapangan untuk mengumpulkan data. Mengapa demikian ?Tentu saja karena setiap orang memiliki pandangan yang seringkali berbeda dalam melihat suatu yang sama ${ }^{11}$.

\section{Pembahasan}

\section{a. Penyelenggaraan Persandian di Kabupaten Bungo Kelembagaan atau Organisasi}

Kelembagaan Persandian pada Pemerintah Kabupaten Bungo dilakukan oleh satuan unit kerja Eselon IV dengan nomenklatur yang digunakan yaitu Sub Bagian Persandian, Bagian Komunikasi Informasi dan Persandian. Dibentuknya unit kerja pelaksanaan urusan persandian setingkat Eselon IV sesuai dengan hasil pemetakan yang ditetapkan dalam Peraturan Bupati Bungo Nomor 55 Tahun 2016 tentang Susunan Organisasi, Tugas dan Fungsi, serta Bagan Struktur Sekretariat Daerah Kabupaten Bungo. Hasil pemetakan tersebut selanjutnya dijadikan dasar penyusunan Peraturan Bupati Bungo Nomor 9 Tahun 2018 tentang Struktur Organisasi dan Tata Kerja Sub Bagian Persandian Bagian Komunikasi Informasi dan Persandian.

Penyusunan nomenklatur dan satuan unit kerja penyelenggara persandian Pemerintah Kabupaten Bungo memperhatikan Peraturan Bupati Bungo Nomor 55 Tahun

\footnotetext{
${ }^{11}$ Lilik Aslichati, H.I.Bambang Prasetyo,Prasetya Irawan,Metode Penelitian Sosial,2011,halm:6.33.
} 
2016 tentang Susunan Organisasi, Tugas dan Fungsi serta Bagan Struktur Sekretariat Daerah Kabupaten Bungo yang berfungsi sebagai berikut ${ }^{12}$.

1. Perencanaan penyusunan dan mengendalikan program kerja serta kegiatan subbagian persandian;

2. Penyiapan bahan penyusunan kebijakan pemerintah daerah dibidang sandi dan telekomunikasi daerah;

3. Pengoordinasian dalam penyiapan bahan pelaksanaan kegiatan pada subbagian persandian;

4. Pengadaan kebutuhan perangkat lunak dan perangkat keras persandian serta kebutuhan sumberdaya pengelola persandian ;

5. Pelaksanaan inventarisasi, penyimpanan dan distribusi perangkat keras dan perangkat lunak persandian ;

6. Pemeliharaan dan perbaikan perangkat lunak dan perangkat keras persandian ;

7. Pengiriman, penyimpanan, pemanfaatan informasi dan penghancuran informasi ;

8. Pengembangan kompetensi sumberdaya manusia persandian melalui program pendidikan, pelatihan, fasilitasi, asistensi, bimbingan teknis worshop dan seminar ;

9. Penyelenggaraan urusan tata usaha Bagian;

10. Penyiapan data dan dokumen sebagai bahan kajian perumusan kebijakan pemerintah daerah bidang sandi dan telekomunikasi daerah;

11. Penyiapan bahan penyusunan perencanaan dan perluasan jaringan telekomunikasi pemerintah daerah ;

12. Pelaksanaan koordinasi petunjuk - petunjuk tentang pengamanan informasi / berita sandi dan telekomunikasi daerah;

13. Penata usahaan sandi dan telekomunikasi daerah;

14. Pengamanan informasi / berita sandi dan telekomunikasi serta berita - berta lainnya;

15. Pelaksanaan koordinasi jaringan komunikasi dan pengelolaan usaha - usaha kegiatan dalam rangka pelayanan serta pengamanan sandi dan telekomunikasi;

16. Pemberian saran dan pertimbangan serta penyampaian laporan hasil telaahan dan analisa kepada atasan sesuai bidang tugasnya;

17. Pelaksanaan tugas kedinasan lainnya sesuai peraturan perundang - undangan, dan sesuai petunjuk serta perintah atasan.

\footnotetext{
${ }^{12}$ Peraturan Bupati Nomor 55 Tahun 2016, tentang Susunan Organisasi, Tugas dan Fungsi serta Bagan Struktur Sekretariat Daerah Kabupaten Bungo.
} 
Sesuai dengan uraian diatas, kelembagaan persandian dan keamanan informasi untuk menyelenggarakan e-goverment dilaksanakan oleh Bagian Komunikasi Informasi dan Persandian. Dengan demikian Sub Bagian Persandian memiliki tugas dan kewenangan yang penuh untuk melaksanakan perumusan bahan dan pelaksanaan kebijakan dibidang keamanan informasi.

Adapun fungsi bagian persandian adalah sebagai berikut ${ }^{13}$ :

1. pengelolaan informasi berklasifikasi dan SDM Sandi ;

2. pengelolaan perangkat lunak dan perangkat keras persandian ;

3. pengelolaan jaring komunikasi sandi ;

4. persandian untuk pengamanan informasi dan infrastruktur TIK ;

5. pengelolaan Security Operation Center (SOC) ;

6. penyelenggaraan statistik sektoral dan laporan pembangunan ;

7. penyusunan laporan bidang sosial ekonomi, pertanian, industri, kesehatan, politik, hukum dan keamanan ;

8. penyusunan integrasi dan analisa data dan statistik pendukung kebijakan ;

9. pendataan dan pemberdayaan jasa titipan daerah (pos) ;

10. pengelolaan menara pemancar/telekomunikasi ;

11. pengelolaan jaringan internet masyarakat ;

12. pengelolaan layanan akses internet tetap dan bergerak untuk masyarakat ;

13. penyelenggaraan dan pengelolaan TIK yang bersifat remote online ;

14. pembinaan telekomunikasi khusus dan radio amatir ;

15. pendayagunaan fasilitas sarana prasarana telekomunikasi untuk pengelolaan pemerintah daerah ;

16. pelaksanaan fungsi kedinasan lain yang diberikan oleh Kepala Dinas.

\footnotetext{
${ }^{13}$ https://dinkominfo.purbalinggakab.go.id/bidang-sandi-statistik-dan-telekomunikasi/, diakses 20 Februari 2020 jam $07.08 \mathrm{Wib}$
} 


\section{b. Tim Persandian Kabupaten Bungo dalam menjaga informasi rahasia pemerintah dalam rangka upaya untuk mewujudkan keutuhan Negara Kesatuan Republik Indonesia}

Adapun kebijakan dalam penyelenggaraan persandian dan keamanan informasi dalam rangka upaya untuk mewujudkan keutuhan Negara Kesatuan Republik Indonesia perlu dilakukan guna terlaksananya pelaksanaan persandian di Kabupaten Bungo. Pemerintah Kabupaten Bungo memiliki struktur dan organisasi dan tata kerja yang membidangi masalah persandian adapun urusan persandian tersebut dilaksanakan oleh Sub bagian Persandian.

Guna terlaksananya urusan persandian di Kabupaten Bungo Pemerintah Kabupaten Bungo berpedoman pada beberapa peraturan, diantaranya :

1. Peraturan Kepala Lembaga Sandi Negara nomor 7 Tahun 2017 Tentang Pedoman Penyelenggaraan Persandian untuk Pengamanan Informasi di Lingkungan Pemerintah Daerah Provinsi dan Kabupaten / Kota.

Peraturan Kepala Lembaga Sandi telah menjadi pedoman bagi pelaksanaan urusan persandian di tingkat Pemerintah Provinsi dan Kabupaten / Kota sesuai dengan isi pada pasal 2 (dua) :

1) Pedoman penyelenggaraan Persandian untuk pengamannan Informasi di lingkungan Pemerintah Daerah provinsi dan kabupaten / kota ini dimaksudkan untuk memberikan acuan bagi Pemerintah Daerah provinsi dan kabupaten / kota dalam melaksanakan kebijakan, program, dan kegiatan penyelenggaraan Persandian untuk pengamanan Informasi bagi Pemerintah Daerah provinsi dan Kabupaten / kota.

2) Pemerintah Daerah menetapkan kebijakan dalam penyelenggaraan Persandian untuk Pengamanan Informasi sesuai dengan kewenangannya.

Hal ini sesuai dengan hasil wawancara dengan Hasan Bahari selaku kepala Sub Bagian Persandian Bagian Komunikasi Informasi dan Persandian Kabupaten Bungo menjelaskan bahwa : "guna mewujudkan pelaksanaan tata kelola penyelenggaraaan urusan persandian dan keamanan informasi rahasia pemerintah, pemerintah Kabupaten Bungo telah memiliki beberapa kebijakan dan peraturan pada Level Pemerintah Daerah Kabupaten. Hal ini sebagai bentuk komitmen yang kuat dalam pelaksanaan urusan pemerintah bidang persandian yaitu dalam menjaga informasi rahasia pemerintah. Dalam rangka upaya untuk mewujudkan keutuhan Negara Kesatuan Republik Indonesia. Kebijakan dan peraturan ini dengan mengacu pada 
Peraturan Kepala Lembaga Sandi Negara yang ditetapkan oleh Lembaga Sandi Negara". ${ }^{14}$

Dari hasil wawancara diatas dapat kita simpulkan bahwa pemerintah Kabupaten Bungo telah memiliki Peraturan yang mengatur tentang urusan persandian yaitu Peraturan Bupati Bungo Keputusan Peraturan Bupati Bungo Nomor 55 Tahun 2016 tentang Susunan Organisasi, Tugas dan Fungsi, Serta Bagan Struktur Sekretariat Daerah Kabupaten Bungo dan SOP di bidang persandian dan keamanan informasi dilingkungan Pemerintah Kabupaten Bungo. Untuk urusan bidang persandian Juga mengikuti peraturan yang ditetapkan oleh Lembaga Sandi Negara.

2. Peraturan Bupati nomor 55 Tahun 2016 Tentang Susunan Organisasi, Tugas dan Fungsi, serta Bagan Struktur Sekretariat Daerah Kabupaten Bungo.

Peraturan Bupati Ini menjadi acuan dan pedoman bagi Sub Bagian Persandian dalam melaksanakan Tugas pokok dan fungsinya sehingga urusan persandian dapat dilaksanakan di Kabupaten Bungo. Hal ini sesuai dengan hasil wawancara peneliti dengan Bapak Amar bagian Organisasi setda Kabupaten Bungo, beliau menjelaskan :

"Tujuan Peraturan ini ( Peraturan Bupati nomor 55 Tahun 2016 ) dibuat yaitu bertujuan untuk mengetahui tugas pokok, dan fungsi dalam melaksanakan perkerjaan"15.

Dari hasil wawancara tersebut dapat kita simpulkan bahwa peraturan Bupati nomor 55 Tahun 2016 dapat dijadikan acuan dan pedoman bagi Sub Bagian Persandian dalam melaksanakan urusan bidang persandian.

Tabel III. Daftar Peraturan tentang Persandian dan Keamanan Informasi

\begin{tabular}{|c|c|c|c|}
\hline No & Nama Peraturan & Uraian & Keterangan \\
\hline 1 & $\begin{array}{l}\text { Peraturan Kepala Lembaga } \\
\text { Sandi Negara Nomor } 7 \\
\text { Tahun } 2017\end{array}$ & $\begin{array}{l}\text { Tentang Pedoman } \\
\text { Penyelenggaraan Persandian } \\
\text { untuk Pengamanan Informasi } \\
\text { di Lingkungan Pemerintah } \\
\text { Daerah Provinsi dan }\end{array}$ & \\
\hline
\end{tabular}

\footnotetext{
${ }^{14}$ Hasil wawancara dengan Hasan Bahari, kepala Sub Bagian Persandian Bagian Komunikasi Informasi, Sekretariat Daerah Kabupaten Bungo.

${ }^{15}$ Hasil wawancara dengan Bpk. Amar Bagian Organisasi Setda Kab. Bungo.
} 


\begin{tabular}{|l|l|l|l|}
\hline & & Kabupaten / Kota. & \\
\hline 2 & Peraturan Bupati Bungo & Tentang Susunan Organisasi, & \\
& Nomor 55 Tahun 2016 & Tugas dan Fungsi, serta & \\
& & Bagan Struktur Skretariat & \\
& & Daerah Kabupaten Bungo & \\
\hline
\end{tabular}

Sumber : Sub Bagian Persandian, Tahun 2018.

c. Hambatan atau Kendala Tim Persandian dalam melaksanakan fungsinya dalam menjaga informasi rahasian pemerintah dalam rangka upaya untuk mewujudkan keutuhan Negara Kesatuan Republik Indonesia

\section{Kurang memahami Tugas dan Fungsi terutama pada pelaksanaan Fungsi Administratif pada SubBagian Persandian}

Hasil wawancara penulis dengan Hasan Bahari selaku Kepala Sub Bagian Persandian Kabupaten Bungo tentang tugas dan fungsi Persandian adalah sebagai berikut :

"Pelaksanaan Fungsi administratif pada SubBagian Persandian merupakan implementasi dari pelaksanaan Peraturan Bupati Bungo Nomor 55 tahun 2016". ${ }^{16}$

Dari wawancara diatas dapat disimpulkan bahwa pelaksanaan tugas dan fungsi Persandian berdasarkan Peraturan Bupati Nomor 55 tahun 2016.

Beliau menambahkan :

"Satu_kegiatan administrasi pada Subbagian Persandian adalah bentuk dari kegiatan mengirim dan menerima berita/ informasi dari instansi atau Organisasi Perangkat Daerah lain yang ada di kabupaten bungo baik berita / informasi dari pemerintah kabupaten (Bupati) ke pemerintah kecamatan._Dua, Mengirim dan menerima berita/informasi dari Organisasi Perangkat Daerah (OPD) ke pemerintah kecamatan dan sebaliknya pengiriman berita /informasi dari pemerintah kecamatan ke Bupati maupun ke Organisasi Perangkat Daerah yang ada di Kabupaten Bungo berita /informasi tersebut dikirim dan diterima melalui SubBagian Persandian selanjutnya diteruskan ke alamat tujuan surat tersebut._Tiga, Begitu juga berita / informasi yang berasal dari pemerintah pusat ke Pemerintah Kabupaten Bungo dikirim melalui Subbagian Persandian lalu diteruskan ke

\footnotetext{
${ }^{16}$ Hasil wawancara dengan Hasan Bahari Kepala Subbagian Persandian Sekretariat Kabupaten Bungo, tanggal 10 April 2018.
} 
Alamat tujuann surat tersebut._Empat,serta berita /informasi dari pemerintah propinsi ke pemerintah Kabupaten Bungo diterima melalui subbagian persandian lalu diteruskan ke alamat tujuan surat tersebut._Lima, begitu juga berita/informasi dari pemerintah kabupaten dikirim ke kabupaten tetangga juga melalui Subbagian Persandian lalu diteruskan ke alamat tujuan surat/ atau berita tersebut" ${ }^{17}$.

Dari hasil wawancara diatas dapat kita simpulkan bahwa kegiatan atau tugas dan fungsi dari Sub Bagian Persandian diantaranya adalah mengirim dan menerima berita/ informasi.

Adapun data Kegiatan administrasi pada Subbagian Persandian dapat dilihat pada tabel berikut :

Tabel 4. Berita/ informasi (surat) dari Pusat, dan Propinsi yang dikirim melalui SubBagian Persandian Kabupaten Bungo Pada Tahun 2016

\begin{tabular}{|c|l|c|c|c|}
\hline NOMOR & \multicolumn{1}{|c|}{ BULAN } & FAXIMILE & EMAIL & JUMLAH \\
\hline 1 & Januari & 57 & 22 & 79 \\
\hline 2 & Februari & 88 & 24 & 112 \\
\hline 3 & Maret & 83 & 18 & 101 \\
\hline 4 & April & 102 & 21 & 123 \\
\hline 5 & Mei & 93 & 20 & 113 \\
\hline 6 & Juni & 63 & 17 & 80 \\
\hline 7 & Juli & 53 & 23 & 76 \\
\hline 8 & Agustus & 69 & 21 & 57 \\
\hline 9 & September & 39 & 18 & 74 \\
\hline 10 & Oktober & 54 & 20 & 70 \\
\hline 11 & November & 52 & 18 & 67 \\
\hline 12 & Desember & 47 & 20 & 1042 \\
\hline Jumlah & & 800 & 242 & 2018 \\
\hline
\end{tabular}

Sumber : Data Sub Bagian Persandian Sekretariat Daerah Kabupaten Bungo 2018.

17 Hasil wawancara dengan Kepala Sub Bagian Persandian. 
Adapun berita /informasi yang masuk melalui Subbagian Persandian pada tahun 2017 dapat dilihat pada tabel berikut :

Tabel 5. Berita/ informasi (surat) dari Pusat, dan Propinsi yang dikirim melalui SubBagian Persandian Kabupaten Bungo

Pada Tahun 2017

\begin{tabular}{|c|l|c|c|c|}
\hline NOMOR & \multicolumn{1}{|c|}{ BULAN } & FAXIMILE & EMAIL & JUMLAH \\
\hline 1 & Januari & 48 & 12 & 60 \\
\hline 2 & Februari & 58 & 16 & 74 \\
\hline 3 & Maret & 56 & 11 & 67 \\
\hline 4 & April & 68 & 3 & 65 \\
\hline 5 & Mei & 64 & 1 & 29 \\
\hline 6 & Juni & 22 & 7 & 59 \\
\hline 7 & Juli & 42 & 17 & 93 \\
\hline 8 & Agustus & 38 & 5 & 81 \\
\hline 9 & September & 19 & 39 & 73 \\
\hline 10 & Oktober & 40 & 41 & 58 \\
\hline 11 & November & 28 & 45 & 788 \\
\hline 12 & Desember & 20 & 38 & 2018. \\
\hline Jumlah & & 553 & 235 & 58 \\
\hline
\end{tabular}

Sumber : Data SubBagian Persandian Sekretariat Daerah Kabupaten Bungo 2018.

Sedangkan berita/ informasi dari Bupati Maupun dari Organisasi Perangkat Daerah Kabupaten Bungo yang dikirim ke kecamatan melalui Subbagian Persandian Kabupaten Bungo adalah sebagai Berikut : 
Tabel 6. Berita/ informasi (surat) dari Bupati, dan Organisasi Perangkat Daerah Kabupaten Bungo yang Dikirim ke kecamatan melalui SubBagian Persandian Kabupaten Bungo

Pada Tahun 2017

\begin{tabular}{|c|l|c|c|c|}
\hline \multirow{2}{*}{ NOMOR } & \multirow{2}{*}{ BULAN } & \multicolumn{2}{|c|}{ BERITA } & \multirow{2}{*}{ JUMLAH } \\
\cline { 2 - 4 } & & MASUK & 27 & 28 \\
\hline 1 & Januari & 1 & 23 & 28 \\
\hline 2 & Februari & 5 & 22 & 23 \\
\hline 3 & Maret & 1 & 23 & 26 \\
\hline 4 & April & 1 & 14 & 20 \\
\hline 5 & Mei & 2 & 24 & 26 \\
\hline 6 & Juni & 6 & 39 & 43 \\
\hline 7 & Juli & 2 & 36 & 38 \\
\hline 8 & Agustus & 4 & 29 & 33 \\
\hline 9 & September & 2 & 43 & 44 \\
\hline 10 & Oktober & 4 & 28 & 31 \\
\hline 11 & November & 1 & 3 & 25 \\
\hline 12 & Desember & & 23 & 26 \\
\hline
\end{tabular}

Sumber : Data Sub Bagian Persandian Sekretariat Daerah Kabupaten Bungo 2018.

Adapun fungsi persandian yang berkaitan dengan administratif persandian di Kabupaten Bungo berdasarkan wawancara peneliti dengan Darmadi selaku Ahli Sandi pada staf persandian Kabupaten Bungo yaitu :

"pengamanan administratif yang bersifat klarifikasi rahasia. Adapun tindakan pengamanan dilakukan bertujuan untuk menghindari kebocoran - kebocoran berita /informasi dari pihak - pihak yang tidak berkepentingan, dengan tujuan agar tidak menimbulkan masalah dikemudian hari serta tidak menimbulkan kegaduhan dimasyarakat atau dikantor instansi kantor itu sendiri". ${ }^{18}$

Dari wawancara diatas dapat kita simpilkan bahwa pengamanan informasi rahasia bertujuan agar tidak menimbulkan kegaduhan. Hal ini juga dijelaskan tentang keterlibatan persandian dalam menjaga informasi rahasia

Darmadi menjelaskan :

"Adapun klasifikasi jenis surat dalam administratif yaitu :_Satu surat biasa, surat biasa yaitu surat yang bersifat umum atau terbuka dan dapat di baca masyarakat luas atau

${ }^{18},{ }^{27}$ Hasil wawancara dengan Darmadi, Ahli Sandi pada Staf Subbagian Persandian Sekretariat Daerah Kabupaten Bungo, tanggal 11 April 2018. 
masyarakat umum._Dua, Surat segera, surat segera yaitu surat yang isinya bersifat segera untuk ditindak lanjuti._Tiga, Surat sangat segerat/ kilat, surat sangat segera/ kilat yaitu surat yang bersifat harus diperioritaskan paling utama dalam pananganannya._Empat, Surat rahasia, surat rahasia yaitu surat yang bersifat tertutup / hanya pihak tertentu yang bisa mengetahui isinya, dan dalam penanganannya harus di rahasiakan dengan tujuan agar tidak terjadi kebocoran isi surat tersebut(sebagai contoh surat sandi cara pengiriman dan penerimaannya dengan sistem persandian. ${ }^{19}$

Dan hasil wawancara peneliti dengan Darmadi diatas tentang klarifikasi berita sandi dapat kita simpulkan bahwa ada klasifikasi jenis surat.

Beliau menjelaskan :

"Bahwa klarifikasi berita sandi diantaranya yaitu :_Satu, Berita /informasi Ekonomi, Contohnya yaitu berita tentang kenaikan harga BBM (bahan bakar minyak), kenaikan harga sembako, penimbunan bahan pangan, pemalsuan/pengoplosan bahan pangan._Dua, Berita/informasi Politik, Contohnya situasi Pemilihan Umum Presiden maupun situasi Pemilihan Umum Kepala Daerah serta situasi Pemilihan Umum Legislatif._Tiga, Berita/informasi Sosial, Contohnya yaitu berita/informasi tentang konflik sosial dimasyarakat dan informasi tentang aktifitas orang asing yang berada di Kabupaten Bungo._Empat, Berita/informasi Agama, Contohnya isu-isu tentang adanya aliran kepercayaan yang dapat dapat menimbulkan kegaduhan maupun konflik dalam masyarakat. Dan isu-isu tentang adanya agama baru yang tidak diakui secara resmi oleh negara Republik Indonesia". 20

Dari wawancara diatas dapat kita simpulkan bahwa ada klasifikasi berita sandi. Sedangkan hasil wawancara penulis dengan Adnan Kholid S.Sos.Staf Kesbang POL Kabupaten Bungo

"konflik sosial itu dapat mengancam keutuhan Negara Kesatuan Republik Indonesia, konflik dapat menggangu jalannya pelaksanaan pemerintahan daerah dan berpotensi mengancam keutuhan Negara Kesatuan Republik Indonesia ${ }^{21}$.

Dari wawancara diatas dapat kita simpulkan bahwa dampak dari konflik sosial adalah mengganggu stabilitas nasional dan daerah.

Adapun data daftar konflik dapat dilihat pada tabel berikut :

\footnotetext{
${ }^{20}$ Hasil wawancara dengan Darmadi Ahli sandi Kabupaten Bungo, tanggal 11 April 2018.

${ }^{21}$ Hasil wawancara dengan Adnan Kholid ,S.Sos. Staf Kesbang Pol Linmas kab.Bungo.
} 
Tabel 7. Konflik selama tahun 2018 di Kabupaten Bungo

\begin{tabular}{|c|c|}
\hline No & Uraian peristiwa \\
\hline 1 & $\begin{array}{l}\text { Pada tanggal } 19 \text { Maret } 2018 \text { sekitar pukul } 10.00 \text { Wib bertempat dikantor } \\
\text { Rio Sungai lilin telah berkumpul warga masyarakat dan pemuda sebanyak } \\
\text { kurang lebih } 200 \text { orang tuk menghadiri rapat penyelesaian tuntutan } \\
\text { warga terkait rusaknya jalan Kab.Bungo akibat aktivitas angkutan Truk } \\
\text { TBS PT SKU, hadir dalampertemuan tersebut diantaranya Camat Tanah } \\
\text { Sepenggal Lintas, Dinas Perhubungan, Kasat Intelkam Polres Bungo, } \\
\text { Danramil, Kapolsek, Rio Sungai Lilin, Tokoh Pemuda dan Perwakilan } \\
\text { Masyarakat. } \\
\text { Dilaporkan sebagai berikut : } \\
\text { 1. Berdasarkan kesepakatan pada hari Rabu tanggal } 14 \text { Maret } 2018 \text { jam } \\
22.30 \text { s/d } 00.45 \text { Wib bertempat dikantor Rio Dusun Sungai Lilin } \\
\text { bahwa pada tanggal } 19 \text { Maret } 2018 \text { akan dilaksanakan pertemuan } \\
\text { lanjutan terkait tuntutan masyarakat tersebut dengan deadline yang } \\
\text { disepakati pada tanggal } 20 \text { Maret } 2018 \text {, jika pada tanggal yang } \\
\text { dimaksud belum diperoleh kesepakatan penyelesaian maka Truk } \\
\text { angkutan TBS PT. SKU tidak diperbolehkan melewati jalan tersebut. } \\
\text { Kesimpulan : } \\
\text { Bahwa sampai dengan tanggal } 19 \text { Maret } 2018 \text { belum didapat } \\
\text { kesepakatan dan solusi untuk penyelesaian konflik jalan masyarakat } \\
\text { dengan PT. SKU. }\end{array}$ \\
\hline 2 & $\begin{array}{l}\text { Pada tanggal } 2 \text { februari pukul } 14.30 \text { Wib. Diaula KPU Bungo, berlangsung } \\
\text { rapat pleno KPU Bungo penyerahan hasil verifikasi Faktual (vertual) } \\
\text { kepada } 11 \text { Parpol lama (peserta Pemilu 2014). Kegiatan dihadiri sekitar } \\
25 \text { orang diantaranya Dailami (Ketua KPU) beserta Komisioner, Ahmadi } \\
\text { dan Harun Al Rasyid (Panwas Kab.Bungo), Ketua/Pengurus } 11 \text { Parpol dan } \\
\text { undangan lainnya. Berkaitan kegiatan tersebut dapat dilaporkan : } \\
\text { 1. Adapun hasil dari verifikasi Faktual maka secara umum seluruh Partai } \\
\text { Politik telah memenuhi syarat (MS) untuk kepengurusan, } \\
\text { keberadaan, domisili kantor, dan keanggotaan. } \\
\text { Namun untuk item keterwakilan } 30 \text { persen perempuan dalam } \\
\text { kepengurusan ada } 5 \text { Partai Politik yang belummemenuhi syarat } \\
\text { (BMS) yaitu; PAN, Partai Demokrat, PBB, PPP, dan Partai Hanura. } \\
\text { Sementara itu, } 6 \text { Partai Politik dinyatakan memenuhi syarat(MS), }\end{array}$ \\
\hline
\end{tabular}




\begin{tabular}{|c|c|}
\hline & $\begin{array}{l}\text { yaitu PDI Perjuangan, Partai Gerindra, Partai Golkar, PKS dan Partai } \\
\text { Nasdem serta PKPI. } \\
\text { 4. Penyerahan berkas dekumen hasil verifikasi Faktual disampaikan oleh } \\
\text { Dailami S.Ag M.Sy (Ketua KPU) didampingi oleh Komisioner KPU dan } \\
\text { disaksikan Panwas Kab.Bungo. } \\
\text { Catatan : } \\
\text { Bagi Partai Politik yang belum memenuhi syarat masih bisa dilakukan } \\
\text { perbaikan karena masih ada jadwal perbaikan yaitu sejak tanggal } 3 \text { s/d } 5 \\
\text { Februari } 2018 \text {. Untuk verifikasi Faktual di Kab.Bungo hanya } 11 \text { Partai } \\
\text { Politik karena PKB Kab.Bungo sejak awal tahap verifikasi tidak ikut } \\
\text { mendaftarkan dan menyerahkan berkas dokumen persyaratan. Kominda } \\
\text { Bungo terus meningkatkan pengawasan dan monitoring perkembangan } \\
\text { dinamika politik pelaksanaan tahapan Pemilu } 2019 \text { sebagai antisipasi } \\
\text { potensi ATHG diwilayah. }\end{array}$ \\
\hline 3 & $\begin{array}{l}\text { Pada tanggal } 2 \text { Februari 2018, pukul } 10.07 \text { Wib di kantor BPMPD } \\
\text { Kab.Bungo sedang berlangsung kegiatan Unjuk Rasa dari masyarakat } \\
\text { Dusun Sungai Tembang Kecamatan Tanah Sepenggal Lintas, hadir dalam } \\
\text { pertemuan tersebut berjumlah } 30 \text { orang antara lain Drs. Tommy Usman, } \\
\text { Msi.(Asisten III Pemerintah Setda Kab Bungo), M.Toupik (Kepala BPMPD } \\
\text { Kab.Bungo), Kompol Samhari Azwar(Kabag OPS Polres Bungo) } \\
\text { Muhammad Rita, S.Sos. MSi.(Tokoh Masyarakat Sungai Tembang), } \\
\text { beserta dua puluh enam orang perwakilan masyarakat, selengkapnya } \\
\text { Dilaporkan sebagai berikut : } \\
\text { A. Sambutan Kepala BPMPD sebagai berikut: } \\
\text { 1. Surat keputusan lembaga Adat bahwa sdr.Tarmizi (Rio Sungai } \\
\text { Tembang) di nikahkan. } \\
\text { BPD sudah melakukan rapat dengan rekomendasi Rio Sungai } \\
\text { Tembang di berhentikan dari Jabatannya. } \\
\text { 3. Bahwa Pemda Bungo sudah tiga kali melakukan pemberhentian } \\
\text { Rio/Kepala Desa namun Pemda Bungo mencabut keputusan tersebut } \\
\text { karena kalah di PTUN. } \\
\text { 4. Yakin lah bahwa keputusan BPD dan lembaga Adat sudah kami } \\
\text { proses masalah ini, dan kami juga sudah meminta pertimbangan ahli } \\
\text { hukum UNJA diJambi dan Kabag Hukum Propinsi Jambi. }\end{array}$ \\
\hline
\end{tabular}




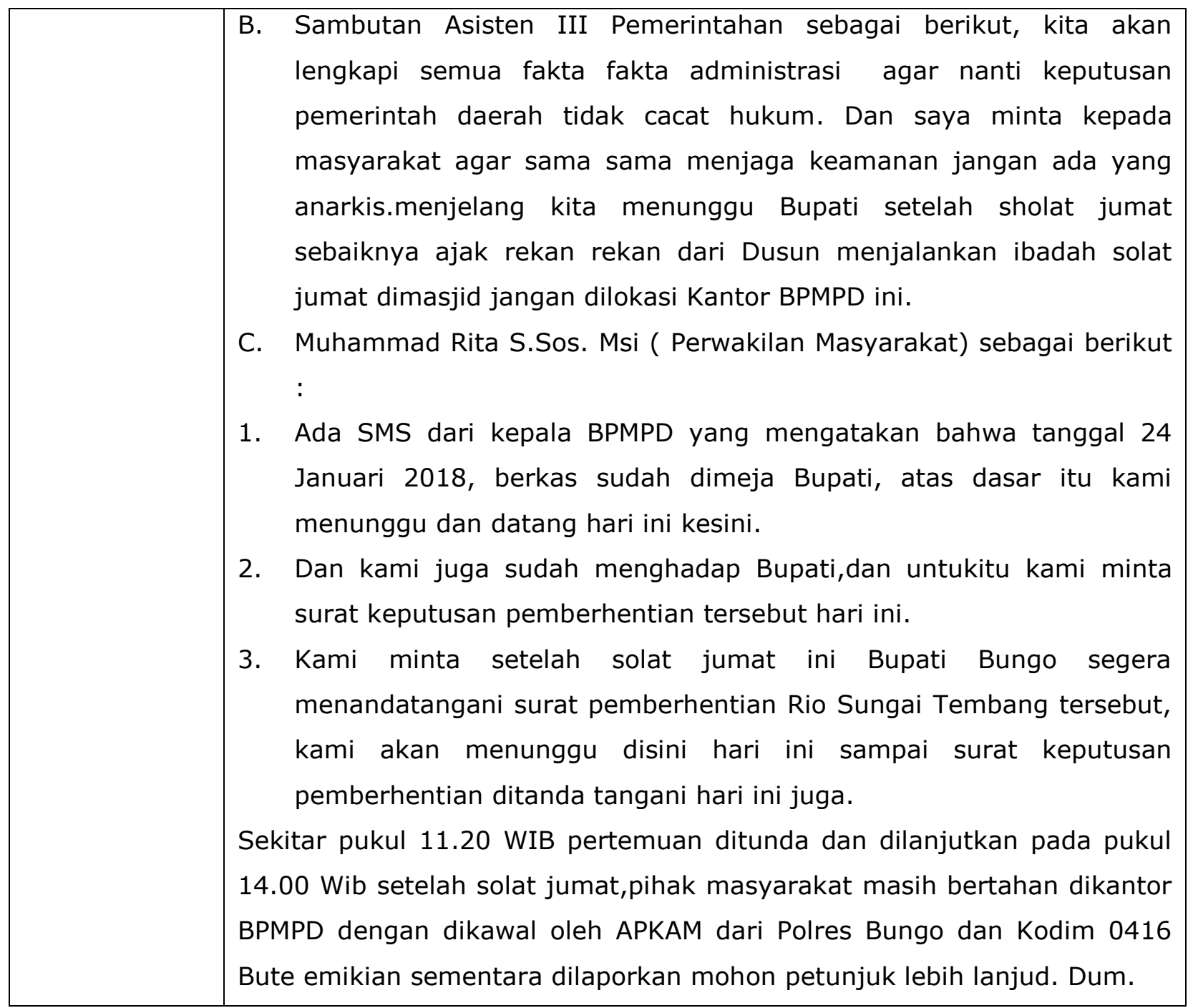

Sumber : Data BPBD Kesbang Pol Kab.Bungo tahun 2018

\section{Kurangnya Sumber Daya Manusia ( SDM ) pada Sub Bagian Persandian}

Dalam melaksanakan tugasnya, Sub Bagian Persandian Kabupaten Bungo memiliki 5 (lima) orang pegawai yang terdiri atas 1 (satu) pejabat struktural dan 4 (empat) orang staf - jika dilihat dari pemenuhan kualifikasi ahli sandi, dari 5 (lima) orang SDM hanya 2 (dua) orng yang telah memiliki kualifikasi ahli sandi. Kondisi tersebut menunjukkan bahwa $60 \%$. kondisi tersebut menunjukkan bahwa sebagian besar SDM yang bertugas di bidang Persandian masih belum memiliki kualifikasi ahli sandi.data tentang kondisi SDM berdasarkan kualifikasi ahli sandi dapat dilihat pada tabel berikut : 
Tabel 8. Kondisi Kualifikasi Ahli Sandi

Pada Sub Bagian Persandian Sekretariat Daerah Kabupaten Bungo Tahun 2018

\begin{tabular}{|c|l|c|c|c|}
\hline \multirow{2}{*}{$\begin{array}{c}\text { N } \\
\mathbf{0}\end{array}$} & \multicolumn{1}{|c|}{\begin{tabular}{c} 
Jaba \\
\cline { 3 - 5 }
\end{tabular}} & \multicolumn{2}{|c|}{ Jumlah } & Persentase \\
\hline 1 & Ka.Sub Bagian & 1 & 0 & $0 \%$ \\
\hline 2 & Staf PNS & 3 & 2 & $60 \%$ \\
\hline 3 & $\begin{array}{l}\text { Staf Pegawai } \\
\text { Kontrak }\end{array}$ & 1 & 0 & 0 \\
\hline & Jumlah & 5 & & $60 \%$ \\
\hline
\end{tabular}

Sumber : Data Sub Bagian Persandian Sekretariat Daerah Kabupaten Bungo, Tahun 2018.

Hasil wawancara dengan Sunadi, S.Sos sebagai Sandiman Tingkat Dasar menjelaskan bahwa :

"Pemerintah Kabupaten Bungo sebenarnya telah memiliki SDM berkualifikasi ahli sandi sejumlah 3 (tiga)) orang. Namun 1 (satu) orang diantaranya dimutasi ke Dinas BPMPD hal ini disebabkan karena promosi jabatan. Sedangkan SDM yang bertugas pada sub Bagian Persandian saat ini belum ada yang menjabat jabatan fungsional sandiman. Dalam meningkatkan SDM persandian serta upaya untuk menambah pengetahuan tentang persandian maka Sub Bagian Persandian Sekretariat Daerah Kabupaten Bungo mengirimkan staf nya untuk mengikuti kegiatan BINTEK (Bimbingan Teknis) bidang Persandian yang diadakan oleh Lembaga Sandi Negara serta mengikuti kegiatann what shop bidang persandian yang diadakan oleh pemerintah pusat maupun pemerintah propinsi". ${ }^{22}$

Dari hasil wawancara diatas dapat kita disimpulkan bahwa untuk meningkatkan SDM bidang Persandian maka Sub Bagian Persandian mengirimkan stafnya untuk mengikuti BINTEK di Lembaga sandi Negara.

Untuk masalah peningkatan SDM di Sub Bagian Persandian Darmadi sebagain Ahli Sandi menjelaskan :

"Sedangkan untuk meningkatkan SDM pendukung bidang persandian di tingkat kecamatan pihak Sub Bagian Persandian belum bisa mengkoordinasikan hal ini dikarenakan terbatasnya anggaran pada pelaksanaan bidang Persandian. Begitu juga mengenai BINTEK dan what shop bidang pengamanan informasi bahwa Sub Bagian Persandian belum pernah mengadakan BINTEK dan What shop ditingkat kecamatan hal ini dikarenakan tidak direncanakan pada pelaksanaan program Sub Bagian Persandian"23.

\footnotetext{
${ }^{22}$ Hasil wawancara dengan Sunadi,Staf Persandian Sekretariat Kabupaten Bungo,tanggal 23 April 2018.

${ }^{23}$ Hasil wawancara dengan Darmadi Staf Persandian Sekretariat Kab.Bungo tanggal 15 mei 2018.
} 


\section{Kurangnya Sarana dan Prasarana pada Sub Bagian Persandian}

Sesuai dengan data yang di peroleh peneliti pada Sub Bagian Persandian bahwa sarana yang digunakan dalam pengiriman maupun penerimaan berita /informasi rahasia pada Sub Bagian Persandian dapat dilihat pada tabel berikut :

Tabel 9. Kondisi Peralatan Sandi Tahun 2018

\begin{tabular}{|c|l|c|c|}
\hline \multirow{2}{*}{$\mathbf{0}$} & $\begin{array}{c}\text { Nama Peralatan } \\
\text { Sandi }\end{array}$ & \multirow{2}{*}{ Jumlah } & $\begin{array}{c}\text { Kondisi dan kesiapan } \\
\text { operasional }\end{array}$ \\
\cline { 3 - 4 } & & 1 & Baik \\
\hline 2 & Secure VPN & 1 & Baik Siap \\
\hline 3 & Crytosoft Pro & 1 & Baik dan Tiap Siap \\
\hline 4 & $\begin{array}{l}\text { Secure Digital Radio } \\
\text { Encryption (Hytera) }\end{array}$ & 30 & \\
\hline & Jumlah & 33 & \\
\hline
\end{tabular}

Sumber : Data Sub Bagian Persandian Sekretariat Daerah Kabupaten Bungo Tahun 2018.

Menurut penjelasan Sunadi, S.Sos staf persandian bahwa :

"sarana yang digunakan untuk mengirim berita dari pemerintah kabupaten ke pemerintah tingkat kecamatan menggunakan sarana radio telekomunikasi namun kondisi sarana radio telekomunikasi di kecamatan saat ini dalam keadaan rusak, sedangkan untuk pengiriman berita dari pemerintah kabupaten ke pemerintah propinsi dan pemerintah pusat menggunakan sarana Faximile. Sebenarnya sub bagian Persandian sudah mengirim surat ke pemerintah kecamatan agar menganggarkan perbaikan radio telekomunikasi namun kenyataan sampai saat ini radio masih belum juga dapat di operasionalkan"24.

Dari wawancara diatas dapat kita simpulkan bahwa sarana radio telekomunikasi yang ada dikecamatan sudah lama rusak dan belum diperbaiki.

Sebagaimana dijelaskan oleh Rukminto Ari P. operator radio telekomunikasi Kecamatan Tanah Sepenggal Lintas, beliau menjelaskan bahwa :

"semenjak radio telekomunikasi mengalami kerusakan beliau sering mendatangi kantor persandian untuk menjemput berita. Hal ini saya lakukan dikarenakan sudah menjadi tanggung jawab, tugas saya adalah:_ Satu, menerima berita._Dua, mengklarifikasi berita._Tiga, mendisposisikan berita kepada atasan._Empat,

\footnotetext{
${ }^{24}$ Hasil wawancara dengan Sunadi, S.Sos. staf persandian Sekretariat Daerah Kab.Bungo tanggal 02 mei 2018.
} 
mengirim / menyampaikan berita ke alamat yang dituju._Lima, mengarsipkan berita". 25

Dari hasil wawancara diatas dapat kami simpulkan bahwa Tupoksi operator radio telekomunikasi sebagaimana disebutkan diatas.

Rukminto Ari P.juga menjelaskan bahwa :

"semenjak radio telekomunikasi rusak beliau menerima berita melalui WA(WhatsApp). Penggunaan aplikasi WhatsApp ini terkendala oleh sinyal yang lelet dan biaya Paket Internet di tanggung sendiri".

Dari penjelasan Rukminto Ari P. Diatas dapat kita simpulkan bahwa radio telekomunikasi kecamatan Tanah sepenggal Lintas mengalami kerusakan.

Begitu juga keadaan radio telekomunikasi di Kecamatan Jujuhan yang saat ini mengelami kerusakan, Atika operator radio telekomunikasi di Kecamatan Jujuhan menjelaskan bahwa:

"radio telekomunikasi di kecamatan Jujuhan sudah lama rusak dan beliau menerima berita menggunakan aplikasi WhatsApp, sedangkan jaringan internet beliau menggunakan fasilitas jaringan wifi kantor".

Atika menambahkan bahwa:

"kendala yang dihadapi adalah ketika kantor mengalami mati lampu. Terkadang mati lampu ini bisa seharian, jika kantor mengalami mati lampu seharian maka beliau tidak dapat menerima berita/informasi dari pemerintah kabupaten".

Dan Atika juga menambahkan bahwa:

"saya menggunakan fasilitas jaringan Wifi kantor, Karena saya jarang membeli Paket Data Internet. Hal ini kerena saya adalah pegawai Honor Kontrak yang gajinya kecil, sedangkan honor operator tidak ada"26.

Dari wawancara diatas dapat kita simpulkan bahwa honor (artinya : sebagai pemotivasi ) operator radio telekomunikasi dikecamatan Jujuhan tidak ada.

Sedangkan operator Radio telekomunikasi kecamatan Pelepat Ilir yakni Dian Mardianis menjelaskan bahwa :

\footnotetext{
${ }^{25}$ Hasil wawancara dengan Rukminto Ari P. Operator radio telekomunikasi Kecamatan Tanah Sepenggal Lintas, tanggal 25 April 2018.

${ }^{26}$ Hasil wawancara dengan Atika Pegawai Honor Kontrak Kecamatan Jujuhan, tanggal 26 April 2018.
} 
"Radio Telekomunikasi tidak dapat dipergunakan lagi hal ini dikarenakan Antena Radio mengalami pergeseran arah karena tertiup angin dan tidak ada yang bisa memperbaiki sedangkan pada saat ini berita/ informasi dari kabupaten ia terima melalui aplikasi What App".

Dian Mardianais menambahkan :

"Adapun kendala yang dihadapi adalah terkadang isi kantong (anggaran/uang) suka minim buat beli paket internat, sedangkan ado maupun tidak ado, pokoknya paket internet jangan sampai kosong walau pun honor belum cair. Hal ini karena kesadaran tentang tanggung jawab sebagai operator radio telekomunikasi". ${ }^{27}$

Dari hasil wawancara diatas dapat kita simpulkan bahwa honor untuk operator kecamatan terlambat untuk di bayarkan.

Menurut penjelasan Sunadi, S.Sos staf persandian bahwa :

"sarana yang digunakan untuk mengirim berita dari pemerintah kabupaten ke pemerintah tingkat kecamatan menggunakan sarana radio telekomunikasi namun kondisi sarana radio telekomunikasi di kecamatan saat ini dalam keadaan rusak, sedangkan untuk pengiriman berita dari pemerintah kabupaten ke pemerintah propinsi dan pemerintah pusat menggunakan sarana Faximile. Sebenarnya sub bagian Persandian sudah mengirim surat ke pemerintah kecamatan agar menganggarkan perbaikan radio telekomunikasi namun kenyataan sampai saat ini radio masih belum juga dapat di operasionalkan"28.

Dari wawancara diatas dapat kita simpulkan bahwa sarana radio telekomunikasi yang ada dikecamatan sudah lama rusak dan belum diperbaiki.

Sebagaimana dijelaskan oleh Rukminto Ari P. operator radio telekomunikasi Kecamatan Tanah Sepenggal Lintas, beliau menjelaskan bahwa :

"semenjak radio telekomunikasi mengalami kerusakan beliau sering mendatangi kantor persandian untuk menjemput berita. Hal ini saya lakukan dikarenakan sudah menjadi tanggung jawab, tugas saya adalah:_Satu, menerima berita._Dua, mengklarifikasi berita._Tiga, mendisposisikan berita kepada atasan._Empat, mengirim / menyampaikan berita ke alamat yang dituju._Lima, mengarsipkan berita". ${ }^{29}$

\footnotetext{
${ }^{27}$ Hasil wawancara dengan Dian Mardianis S.Sos. Staf Kecamatan Pelepat Ilir.tanggal 16 Mei 2018.

${ }^{28}$ Hasil wawancara dengan Sunadi, S.Sos. staf persandian Sekretariat Daerah Kab.Bungo tanggal 02mei 2018.

${ }^{29}$.Hasil wawancara dengan Rukminto Ari P. Operator radio telekomunikasi Kecamatan Tanah Sepenggal Lintas, tanggal 25 April 2018.
} 
Dari hasil wawancara diatas dapat kami simpulkan bahwa Tupoksi operator radio telekomunikasi sebagaimana disebutkan diatas.

Rukminto Ari P.juga menjelaskan bahwa :

"semenjak radio telekomunikasi rusak beliau menerima berita melalui WA(WhatsApp). Penggunaan aplikasi WhatsApp ini terkendala oleh sinyal yang lelet dan biaya Paket Internet di tanggung sendiri".

Dari penjelasan Rukminto Ari P. Diatas dapat kita simpulkan bahwa radio telekomunikasi kecamatan Tanah sepenggal Lintas mengalami kerusakan.

Begitu juga keadaan radio telekomunikasi di Kecamatan Jujuhan yang saat ini mengelami kerusakan, Atika operator radio telekomunikasi di Kecamatan Jujuhan menjelaskan bahwa:

"radio telekomunikasi di kecamatan Jujuhan sudah lama rusak dan beliau menerima berita menggunakan aplikasi WhatsApp, sedangkan jaringan internet beliau menggunakan fasilitas jaringan wifi kantor".

Atika menambahkan bahwa:

"kendala yang dihadapi adalah ketika kantor mengalami mati lampu. Terkadang mati lampu ini bisa seharian, jika kantor mengalami mati lampu seharian maka beliau tidak dapat menerima berita/informasi dari pemerintah kabupaten".

Dan Atika juga menambahkan bahwa:

"saya menggunakan fasilitas jaringan Wifi kantor, Karena saya jarang membeli Paket Data Internet. Hal ini kerena saya adalah pegawai Honor Kontrak yang gajinya kecil, sedangkan honor operator tidak ada" ${ }^{30}$.

Dari wawancara diatas dapat kita simpulkan bahwa honor (artinya : sebagai pemotivasi ) operator radio telekomunikasi dikecamatan Jujuhan tidak ada.

Sedangkan operator Radio telekomunikasi kecamatan Pelepat Ilir yakni Dian Mardianis menjelaskan bahwa :

"Radio Telekomunikasi tidak dapat dipergunakan lagi hal ini dikarenakan Antena Radio mengalami pergeseran arah karena tertiup angin dan tidak ada yang bisa memperbaiki sedangkan pada saat ini berita/ informasi dari kabupaten ia terima melalui aplikasi What App".

Dian Mardianais menambahkan :

"Adapun kendala yang dihadapi adalah terkadang isi kantong (anggaran/uang) suka minim buat beli paket internat, sedangkan ado maupun tidak ado, pokoknya paket

\footnotetext{
${ }^{30}$ Hasil wawancara dengan Atika Pegawai Honor Kontrak Kecamatan Jujuhan, tanggal 26 April 2018.
} 
internet jangan sampai kosong walau pun honor belum cair. Hal ini karena kesadaran tentang tanggung jawab sebagai operator radio telekomunikasi". ${ }^{31}$

Dari hasil wawancara diatas dapat kita simpulkan bahwa honor untuk operator kecamatan terlambat untuk di bayarkan.

\section{Kurangnya Anggaran pada Sub Bagian Persandian}

Anggaran pelaksanaan kegiatan persandian dan keamanan informasi pada tahun 2017 bersumber dari APBD ( Anggaran Pendapatan dan Belanja Daerah ) Pemerintah Kabupaten Bungo dengan jumlah anggaran sebesar : Rp. 39.800.000,- ( Tiga puluh sembilan juta delapan ratus ribu rupiah ). Adapun tabel anggaran adalah sebagai berikut :

Tabel 10. Anggaran Sub Bagian Persandian Tahun 2018

\begin{tabular}{|c|l|l|}
\hline No & Jenis Kegiatan & Jumlah anggaran \\
\hline 1 & Belanja Pegawai & 16.912 .000 \\
\hline 2 & Belanja Barang dan Jasa & 22.888 .000 \\
\hline & Jumlah & 39.800 .000 \\
\hline
\end{tabular}

Sumber : Sub Bagian Persandian Sekretariat Daerah Kabupaten Bungo, tahun 2018

Sesuai dengan data yang di peroleh peneliti bahwa anggaran yang di ajukan oleh Sub Bagian Persandian tidak semuanya disetujui oleh pemerintah daerah hal ini sesuai dengan hasil wawancara dengan Hasan Bahari sebagai kepala Sub Bagian Persandian,, beliau menjelaskan :

"Kendala selanjudnya adalah Anggaran yang kita usulkan tidak semua disetujui, dikarenakan ada perioritas anggaran, artinya anggaran yang disetujui adalah anggaran untuk program - program yang perioritas hal ini mengingat kemampuan pemerintah daerah dalam pendanaan"32.

\section{Upaya Tim Persandian dalam mengatasi hambatan dalam menjaga informasi rahasia pemerintah dalam rangka upaya untuk mewujudkan keutuhan Negara Kesatuan Republik Indonesia}

Adapun upaya - upaya yang dilakukan dalam mengatasi hambatan dalam menjaga informasi rahasia pemerintah dalam rangka upaya untuk mewujudkan keutuhan Negara

\footnotetext{
${ }^{31}$ Hasil wawancara dengan Dian Mardianis S.Sos. Staf Kecamatan Pelepat Ilir.tanggal 16 Mei 2018.

${ }^{32}$ Hasil wawancara dengan Hasan Bahari, kepala Sub Bagian Persandian Sekretarian Daerah Kabupaten Bungo,tanggal 12 April 2018.
} 
Kesatuan Republik Indonesia menurut Darmadi selaku Ahli Sandi pada Sub Bagian Persandian Sekretariat Daerah di Kabupaten Bungo adalah :

1. Meningkatkan kesadaran bagi Staf Persandian Kabuapaten Bungo mengenai pentingnya menjaga informasi rahasia pemerintah guna melaksanakan Tugas dan Fungsi bidang Persandian. bahwa peningkatan kesadaran tersebut dilakukan secara terus menerus guna menjaga /mengamankan informasi rahasia pemerintah. Adapun cara yang ditempuh misalnya dengan mengarsipkan berita/ informasi tersebut. Serta jika sudah tidak diperlukan pemusnahan berita/ informasi tersebut dapat dilakukan.

2. Meningkatkan Sumberdaya Manusia (SDM) Bidang Persandian. bahwa meningkatkan kemampuan bidang Persandian adalah penting guna memenuhi kebutuhan tenaga Ahli Sandi pada Sekretariat Daerah Kabupaten Bungo. Adapun cara yang dilakukan diantaranya dengan mengikuti Diklat Sandi yang diadakan oleh Lembaga Sandi Negara.

3. Meningkatkan koordinasi baik dengan Persandian Propinsi maupun dengan operator Radio Telekomunikasi yang ada di kecamatan hal ini sangat penting untuk dilakukan guna mengetahui serta mendapatkan berita/ informasi maupun kendala - kendala yang ada pada setiap kecamatan terutama dalam pelaksanaan tugas" ${ }^{\prime 33}$.

Dari hasil wawancara diatas dapat kita simpulkan bahwa ada upaya dari pemerintah daerah dalam mengatasi kendala - kendala yang ada. Yaitu :

1. Meningkatkan kesadaran bagi staf persandian Kabupaten Bungo mengenai pentingnya menjaga informasi rahasia pemerintah guna melaksanakan Tugas dan Fungsi bidang Persandian. bahwa peningkatan kesadaran tersebut dilakukan secara terus menerus guna menjaga /mengamankan informasi rahasia pemerintah. Adapun cara yang ditempuh misalnya dengan mengarsipkan berita/ informasi tersebut. Serta jika sudah tidak diperlukan pemusnahan berita/ informasi tersebut dapat dilakukan.

2. Meningkatkan Sumberdaya Manusia (SDM) Bidang Persandian. bahwa meningkatkan kemampuan bidang Persandian adalah penting guna memenuhi kebutuhan tenaga Ahli Sandi pada Sekretariat Daerah Kabupaten Bungo. Adapun cara yang dilakukan diantaranya dengan mengikuti Diklat Sandi yang diadakan oleh Lembaga Sandi Negara.

3. Meningkatkan koordinasi baik dengan Persandian Propinsi maupun dengan operator Radio Telekomunikasi yang ada di kecamatan hal ini sangat penting untuk dilakukan guna mengetahui serta mendapatkan berita/ informasi maupun kendala - kendala yang ada pada setiap kecamatan terutama dalam pelaksanaan tugas.

\footnotetext{
${ }^{33}$ Hasil wawancara dengan Darmadi, Ahli Sandi pada Sub Bagian Persandian Sekretariat Daerah Kab.Bungo tanggal 16 Mei 2018.
} 


\section{Kesimpulan Dan Saran}

\section{a. Kesimpulan}

Berdasarkan hasil analisis dan uraian yang telah ditemukan pada bab - bab sebelumnya dari sekripsi ini, peneliti menrik kesimpulan dan saran - saran. Adapun kesimpulannya sebagai berikut :

1. Pelaksanaan Tugas dan Fungsi Tim Persandian kabupaten Bungo dalam menjaga informasi rahasia pemerintah dalam rangka upaya untuk mewujudkan keutuhan Negara Kesatuan Republik Indonesia (NKRI) belum berjalan dengan baik. Hal tersebut dibuktikan dengan adanya kesadaran dan tanggung jawab Tim Persandian yang kurang terhadap Tugas dan Fungsi Bidang Persandian. Hal tersebut dapat dibuktikan dengan adanya hal - hal sebagai berikut :

a). Tidak adanya upaya untuk memperbaiki peralatan radio telekomunikasi yang rusak terutama di kecamatan yang mengalami kerusakan sehingga pengiriman berita/ informasi dilakukan melalui aplikasi What App.

b). Tidak adanya pendidikan atau BINTEK maupun what shop bidang persandian bagi Operator- operator Radio Telekomunikasi di tingkat kecamatan yang dapat mendukung pelaksanaan tugas dan fungsi bidang persandian.

c). Kurangnya anggaran alokasi dibidang persandian. Hal ini di buktikan dengan tidak diperbaikinya sarana alat radio telekomunikasi yang telah rusak. Sedangkan alat radio telekomunikasi tersebut merupakan sarana pendukung utama dalam penyampaian berita/ informasi dari pemerintah kabupaten ke pemerintah kecamatan.

2. Hambatan atau kendala yang dihadapi Tim Persandian dalam melaksanakan fungsinya dalam menjaga informasi rahasia pemerintah dalam rangka upaya untuk mewujudkan keutuhan Negara Kesatuan Republik Indonesia adalah sebagai berikut :

a. Kurangnya kesadaran dan dukungan penuh dari atasan atau pejabat yang berwenang terhadap pelaksanaan tugas dan fungsi persandian hal ini di buktikan dengan tidak adanya honor operator radio telekomunikasi di sebagian kecamatan sedangkan di sebagian kecamatan ada honor bagi operator radio telekomunikasi. Sedangkan pemberian honor bagi operator radio telekomunikasi ini dapat menjadi motivasi dalam meningkatkan pelaksanaan tugas. Tidak adanya sarana dari pemerintah dalam pelaksanaan tugas dan fungsi di bidang persandian. Hal ini dapat di buktikan dengan rusaknya sarana radio telekomunikasi sehingga pengiriman berita / informasi melalui aplikasi What $A p p$, dalam penggunaan aplikasi What App ini menggunakan HP milik 
pribadi sehingga biaya untuk paket data jaringan internet juga biaya pribadi, dan penggunaan aplikasi What App ini merupakan inisiatif dari staf persandian guna mengatasi permasalahan yang ada.

\section{b. Saran}

Penulis ingin memberikan saran - saran sehubungan dengan penelitian yang dilakukan, sebagai masukan untuk meningkatkan kinerja dalam melaksanakan tugas dan Fungsi di bidang persandian pada Sub Bagian Persandian Sekretariat Daerah Kabupaten Bungo, sebagai berikut :

1. Untuk meningkatkan pelaksanaan tugas dan fungsi bidang persandian dalam menjaga informasi rahasia pemerintah dalam rangka upaya untuk mewujudkan keutuhan Negara Kesatuan Republik Indonesia perlu dilakukan peningkatan kualitas Sumber Daya Manusia(SDM) bidang persandian. Misalnya dengan memberikan pendidikan maupun BINTEK bidang persandian bagi staf persandian maupun bagi seluruh operator radio telekomunikasi di kecamatan. Tujuannya untuk memberikan peningkatan kualitas pelaksanaan tugas dan fungsi di bidang persandian.

2. Untuk mengatasi hambatan dalam pelaksanaan tugas dan fungsi bidang persandian di Kabupaten Bungo dalam menjaga informasi rahasia pemerintah dalam rangka upaya untuk mewujudkan keutuhan Negara Kesatuan Republik Indonesia peneliti menyarankan agar Pemerintah Kabupaten Bungo mengganti sarana radio telekomunikasi yang telah rusak dengan sarana / peralatan laptop yang dilengkapi dengan modem sebagai jaringan internet. Hal ini perlu dilakukan karena sarana radio telekomunikasi yang ada di kecamatan bayak mengalami kerusakan dan bila di perbaiki tentu memerlukan biaya yang tinggi. Selain biayanya yang tinggi penggunaan radio telekomunikasi ini bayak gangguannya terutama bila ada angin kencang maka antena akan berubah arah sehingga sinyal sering terggu, dan bila ada hujan petir maka sarana radio telekomunikasi rentan sekali kena petir.

3. Untuk mengatasi hambatan dalam melaksanakan tugas dan fungsi di bidang persandian di Kabupaten Bungo dalam menjaga informasi rahasia pemerintah dalam rangka upaya untuk mewujudkan keutuhan Negara Kesatuan Republik Indonesia, peneliti menyarankan agar pemerintah Kabupaten Bungo berupaya untuk meningkat anggaran di bidang persandian hal ini perlu dilakukan guna meningkatkan program - program dalam perencanaan di bidang 
persandian sehingga dapat meningkatkan kualitas dalam pelaksanaan tugas dan fungsi di bidang persandian. Serta pelaksanaan tugas dan fungsi persandian menjadi lebih baik.

4. Penelitian lebih mendalam tentang persandian di Kabupaten Bungo masih sangat luas cakupannya. Kepada peneliti lain topic-topik tentang efektivitas persandian dalam menjaga rahasia Negara di Kabupaten Bungo, kendala-kendala bagian Persandian dalam melaksanakan tugas pokok dan fungsinya (tupoksi) juga penting untuk dilkukan.

\section{DAFTAR PUSTAKA}

\section{Buku-Buku}

Brian Prabaswara, Kamus Praktis Bahasa Indonesia, Lingkar Media.

Keputusan Menteri Dalam Negeri, Nomor 20 Tahun 2000, Tentang Penyelenggaraan Sandi dan Telekomunikasi Di Jajaran Departemen Dalam Negeri.

Lilik Aslichati,H.I. Bambang Prasetyo, Prasetya Irawan,2011. Metode Penelitian Sosial, Jakarta.

Onong Uchjana Effendy. 2002 Ilmu Komunikasi Teori dan Praktek, PT Rosdakarya.

Peraturan Bupati Bungo Nomor 55 Tahun 2016, Tentang Susunan Organisasi,Tugas dan Fungsi serta Bagan Struktur Sekertariat Daerah Kabupaten Bungo.

Sugiyono. 2015. Metode Penelitian Kuantitatif,Kualitatif, dan R\&D, Alfa Beta : Bandung.

Undang - undang Nomor 23 Tahun 2014, Tentang Pemerintah Daerah.

Yanuar Ikbar, MA. 2012. Metode Penelitian Sosial Kualitatif, Bandung.

\section{Data Internet}

Copyright Lemsaneg RI. 2007 Jelajah Kriptologi.

https://bungoindependent.id/read/2020/01/24/10993/dis-kominfo-jadi-pusat-informasi-dan-data, (diakses 20 Februari 2020 jam 06.53 Wib)

${ }^{1}$ https://dinkominfo.purbalinggakab.go.id/bidang-sandi-statistik-dan-telekomunikasi/, (diakses 20 Februari 2020 jam $07.08 \mathrm{Wib})$ 
http://www.id.wikipedia.org/wiki/jargon(diakses20 februari2018,jam 10.52 WIB). http://www.merrian-webster.com/dictionarry/jargon(diakses 20 februari 2018, jam10.53 WIB). 